\title{
Development Problems and Countermeasures of Characteristic Towns in Liaoning Province
}

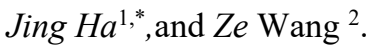 \\ ${ }^{1}$ Master tutor,Ph.D., Shenyang Jianzhu University,China \\ ${ }^{2}$ Master of Shenyang Jianzhu University,China
}

\begin{abstract}
This paper discusses the establishment and construction of characteristic towns at all levels in Liaoning Province, including 13 national characteristic towns, 20 provincial characteristic villages and towns and 11 industrial characteristic towns, and then analyzed the problems and obstacles encountered in the construction of these towns, puts forward some suggestions and strategies to solve these problems, in order to provide some reference for the construction of characteristic towns in Liaoning Province.
\end{abstract}

\section{Introduction}

In 2014, Yunqi town in Hangzhou, Zhejiang Province appeared in people's eyes for the first time, the state successively issued relevant policies on the construction of characteristic towns. The construction of the characteristic town then "bloomed everywhere" in the country. The application, project establishment, planning and construction of characteristic towns in Liaoning Province have also been carried out. Liaoning Province is the bridgehead for the revitalization of the old industrial base in northeast China. With the revitalization of the old industrial base, the construction of the newtype urbanization and characteristic towns have very important era and strategic significance. However, we cannot ignore that while the construction of characteristic towns in Liaoning Province has made some achievements, some problems have inevitably arisen. These problems seriously restrict the development of characteristic towns, so it is necessary to in-depth study, solve the problems, make the construction of characteristic towns become a new economic hot spot to promote the development of new urbanization and promote the upgrading of industrial structure.

\section{Types of characteristic towns in Liaoning Province.}

\subsection{3 national characteristic towns.}

October 14, 2016, The Ministry of Housing and urbanrural development announced the first batch of 127 characteristic towns with Chinese characteristics.Among them, four towns in Liaoning Province, namely, Xietun town in Wafangdian city, Dalian, Gushan town in Donggang city, Dandong city, Tanghe town in
Gongchangling district, Liaoyang city, and Zhaochuanhe town in Dawa district, Panjin city, were on the list.On August 28,2017, the Ministry of Housing and urbanrural development announced the second batch of 276 characteristic towns, including Shijianfang town in Faku County, Shenyang City, Liaoning Province, and Xiongyue town, Bayuquan district, Yingkou city.

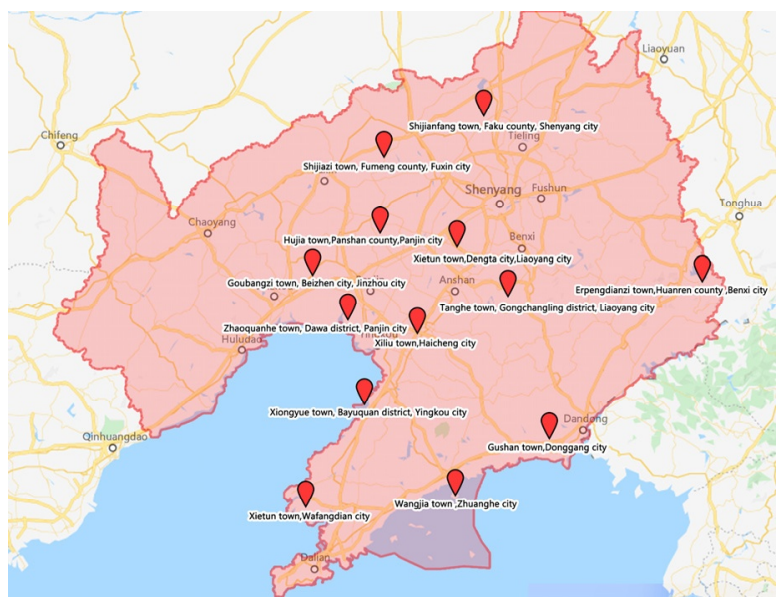

Fig. 1 Distribution of national characteristic towns in Liaoning Province Source: Author's drawing.

At present, a total of 13 small towns in Liaoning Province have been rated as national-level characteristic towns. Their distributions are shown in Figure 1. These towns have completed the preparation and evaluation of relevant plans.In addition,carried out partial construction and investment attraction according to the plan, However, some small towns also appear planning is not in line with the reality, it is difficult to land the problem, is currently adjusting the planning. The construction situation of the 13 towns is different. Some towns have a good overall 
construction situation, such as Xiliu town and Wangjia town, but some towns also show various problems.

\subsection{0 characteristic villages and towns in Liaoning Province.}

In March 2018, the office of the leading group for the construction of characteristic towns and villages in Liaoning Province released the first batch of provincial characteristic towns and villages in Liaoning province, including the small town of kangyang leisure travel, xinglongpu town, xinmin city, and the small town of characteristic liquor, daguizi town, faku county, and 20 other towns and villages were included in the list. Their distribution is shown in figure 2 .

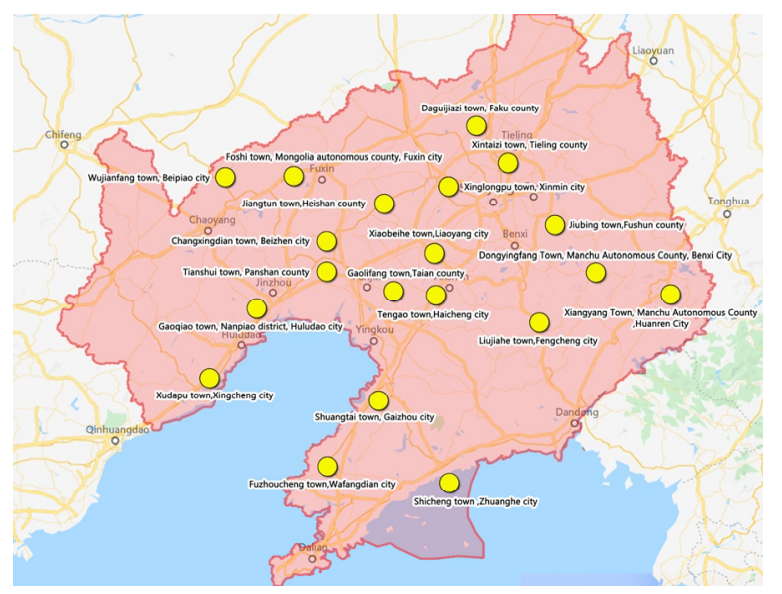

Fig. 2 Distribution of 20 characteristic towns in Liaoning Province.

Source: Author's drawing.

At present, these towns have completed the planning works, and one after another through the project review, the construction of the towns are starting.

\subsection{1 industrial characteristic towns in Liaoning Province.}

In May 2018, 15 departments, including the provincial development and reform commission, the provincial party committee's publicity department, and the provincial commission of industry and information technology, jointly issued by the "About the characteristics of the first industry in Liaoning Province town create list notice". Announced the first batch includes 11 provincial-level towns with industrial characteristics, including Yongan machine tool town in
Shenyang city and Jinpu health town in Dalian city . There distribution are shown in figure 3.The towns have completed the planning work at present.

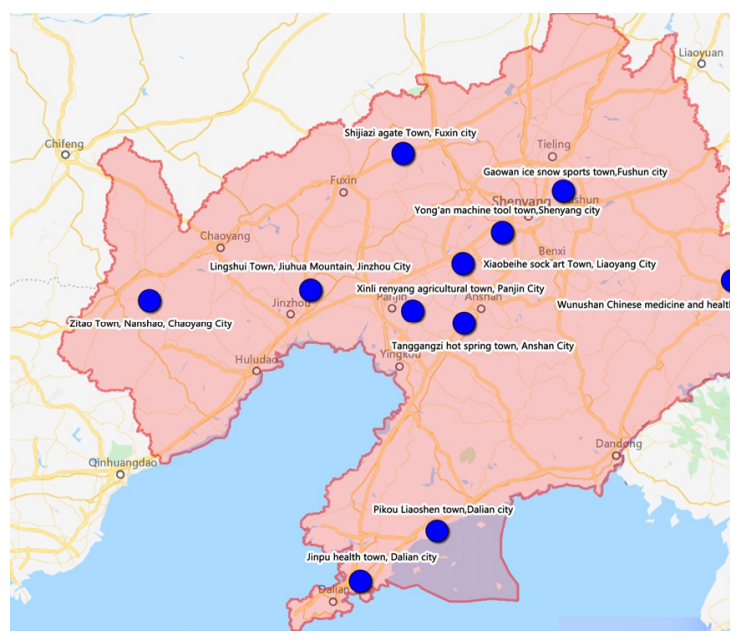

Fig. 3 Distribution of 11 industrial characteristic town in Liaoning Province. Source: Author's drawing.

Since the provincial government issued the guidance on promoting the construction of characteristic towns in 2016.In 2016 and 2017, the government of Liaoning Province released two batches of provincial-level cultivation lists of characteristic villages and towns. Each year, 50 townships were selected, and a total of 100 townships were included in the cultivation list.These towns and villages are characterized by Business processing, Historical culture, Leisure and health preservation, Ethnic characteristics, Island tourism, Innovative industries, Recycling economy, etc. Their distributions also spread throughout Liaoning Province each prefecture-level cities.

\section{Problems existing in the construction of characteristic towns in Liaoning Province.}

Among the above-mentioned small characteristic towns with various kinds at various levels, Liaoning Province has built 13 small towns with national characteristics relatively well. The following with these 13 national level characteristic small towns as examples to discuss the Liaoning Province characteristic towns' construction situation and the existence main questions. 
Table 1. List of national characteristic towns in Liaoning Province.

\begin{tabular}{|c|c|c|c|c|}
\hline Name of characteristic town & Town type & $\begin{array}{l}\text { approved } \\
\text { time }\end{array}$ & $\begin{array}{c}\text { Industry } \\
\text { characteristics }\end{array}$ & The main resources \\
\hline Wafangdian city, Xietun town & ecotourism & In 2016 & $\begin{array}{l}\text { Hot spring tourism, } \\
\text { facility agriculture, } \\
\text { modern fishing }\end{array}$ & Xiangzhou garden city \\
\hline $\begin{array}{l}\text { Tanghe town, Gongchangling } \\
\text { district, Liaoyang city }\end{array}$ & Suburban type & In 2016 & $\begin{array}{ll}\text { Hot } & \text { spring } \\
\text { vacation, } & \\
\text { agriculture } & \\
\end{array}$ & Tanghe Hot springs \\
\hline Donggang city Gushan town & $\begin{array}{l}\text { Historical } \\
\text { culture type }\end{array}$ & In 2016 & $\begin{array}{l}\text { Tourism, fishing, } \\
\text { agriculture, } \\
\text { industry }\end{array}$ & $\begin{array}{l}\text { Dagushan ancient } \\
\text { architecture group }\end{array}$ \\
\hline $\begin{array}{l}\text { Zhaoquanhe town, Dawa } \\
\text { district, Panjin city }\end{array}$ & Ecotourism & In 2016 & $\begin{array}{lr}\begin{array}{l}\text { Northeast } \\
\text { tourism, } \\
\text { tourism }\end{array} & \text { folk } \\
& \\
\end{array}$ & $\begin{array}{l}\text { Red beach wetland } \\
\text { resources }\end{array}$ \\
\hline $\begin{array}{l}\text { Shijianfang town, Faku } \\
\text { county, Shenyang city }\end{array}$ & $\begin{array}{l}\text { New type of } \\
\text { industry }\end{array}$ & In 2017 & $\begin{array}{lr}\text { General } & \text { aviation } \\
\text { core } & \text { industries, } \\
\text { leisure } & \text { sports } \\
\text { tourism } & \end{array}$ & China navigable town \\
\hline Wangjia town Zhuanghe city & Ecotourism & In 2017 & $\begin{array}{l}\text { Fishing and } \\
\text { tourism }\end{array}$ & $\begin{array}{c}\text { Beiku town, Dalian city } \\
\text {, China }\end{array}$ \\
\hline $\begin{array}{l}\text { Shijiazi town, Fumeng } \\
\text { county, Fuxin city }\end{array}$ & $\begin{array}{c}\text { Characteristic } \\
\text { industry }\end{array}$ & In 2017 & $\begin{array}{l}\text { Agate specialty } \\
\text { industry }\end{array}$ & China agate base \\
\hline Haicheng Xiliu town & $\begin{array}{l}\text { Characteristic } \\
\text { industry }\end{array}$ & In 2017 & $\begin{array}{c}\text { Garment } \\
\text { production and } \\
\text { processing industry }\end{array}$ & $\begin{array}{c}\text { Chinese trousers } \\
\text { industry name town } \\
\text { Chinese cotton-padded } \\
\text { clothing town }\end{array}$ \\
\hline $\begin{array}{c}\text { Huanren county Erpengdianzi } \\
\text { town }\end{array}$ & $\begin{array}{l}\text { Agricultural } \\
\text { type }\end{array}$ & In 2017 & $\begin{array}{l}\text { Ginseng industry as } \\
\text { the leading industry }\end{array}$ & $\begin{array}{l}\text { Wild ginseng is the } \\
\text { main feature }\end{array}$ \\
\hline $\begin{array}{l}\text { Xiongyue town, Bayuquan } \\
\text { district, Yingkou city }\end{array}$ & Ecotourism & In 2017 & $\begin{array}{l}\text { Maternal love } \\
\text { culture and hot } \\
\text { spring health care } \\
\text { industry }\end{array}$ & $\begin{array}{l}\text { Respect mother holy } \\
\text { land wanger mountain, } \\
\text { Xiongyue hot spring }\end{array}$ \\
\hline $\begin{array}{l}\text { Goubangzi town, Beizhen } \\
\text { city, Jinzhou city }\end{array}$ & $\begin{array}{l}\text { Characteristic } \\
\text { industry }\end{array}$ & In 2017 & $\begin{array}{l}\text { Chemical industry, } \\
\text { building materials, } \\
\text { smoked chicken, } \\
\text { metallurgical } \\
\text { machinery } \\
\end{array}$ & $\begin{array}{l}\text { Gutong smoked } \\
\text { chicken }\end{array}$ \\
\hline Tongerbao town, Dengta city & $\begin{array}{c}\text { Characteristic } \\
\text { industry }\end{array}$ & In 2017 & The fur industry & The fur capital of China \\
\hline $\begin{array}{l}\text { Wujia town, Panshan County, } \\
\text { Panjin city }\end{array}$ & $\begin{array}{c}\text { Agricultural } \\
\text { industrial type }\end{array}$ & In 2017 & $\begin{array}{l}\text { Panjin rice, river } \\
\text { crab }\end{array}$ & $\begin{array}{l}\text { The first town of river } \\
\text { crabs in north China }\end{array}$ \\
\hline
\end{tabular}

Source: the author sorted out according to the investigation.

\section{The strategy of characteristic town construction in Liaoning Province.}

\subsection{Grasp the opportunity of land space planning, scientific planning of land.}

On May 23,2019, the Central People's Government of the Communist Party of China (CPC) issued the "several opinions of the State Council on establishing a territorial space planning system and supervising its implementation, " proposing the basic establishment of a territorial space planning system by 2020. Liaoning Province should fully grasp this opportunity, scientifically evaluate the carrying capacity of resources and environment and the suitability of land space development, adjust the land use, and reserve enough land for the construction of characteristic towns.

\subsection{Establish and improve the government management system and innovate the system and mechanism.}

Characteristics are the core of the construction of characteristic towns. In the actual project construction, a suitable development mechanism should be established according to the unique resource endowment of each town, so as to stimulate the vitality of the industrial chain of characteristic towns and provide more innovative space for the construction of characteristic towns. The construction and operation of characteristic towns should be market-oriented, and promote the construction of characteristic towns in the way of government-led, enterprise-led and market-oriented operation. 


\subsection{Carry out accurate characteristic industry localization, take the industry as the core.}

On the basis of sticking to the core leading industry, extending the industrial chain. To promote the crossborder integration of multiple planning integration in small towns with special features, so that core industries, supporting industries and Derivative Through integrating innovation to find the characteristics of small town. Combined with the history of the local cultural and specific environment for development and construction in the light of local conditions. Avoid the phenomenon of "one side of a thousand towns" as far as possible.

\subsection{Fully excavate the regional cultural characteristics and create unique style and features.}

The establishment of characteristic towns should not only build characteristic industries and create characteristic brands, but also pay close attention to the development of soft power, such as the inheritance and development of traditional culture. Pay attention to the coordination and unification of the landscape and humanities of small towns. The height and density of the building should be controlled within a proper range. And the shape and color of the building should be coordinated with the overall style and appearance. Integrated with the overall environment.

\subsection{Strengthen the financial support of small towns with special features, and help the construction of small towns.}

Financial institutions, as capital suppliers, should actively respond to the national financing encouragement policies and strengthen financial support for the construction of characteristic towns. At the same time, governments at all levels and small and medium-sized microfinance institutions should also be actively involved in the financial innovation and financial tool, product innovation. Make the small and medium-sized microfinance institutions to constantly optimize the financing structure, provide more financial support for the characteristics of small town construction, meet the demand of characteristic town construction funds.

\subsection{Increase efforts to introduce and cultivate talents and build an innovation platform.}

It is difficult to achieve a high level if there is no relevant talent in the construction of characteristic towns, so we should continue to introduce and cultivate talents in characteristic towns. At the provincial level, efforts should be stepped up to introduce talents to improve public services and residents' living standards by improving the town's infrastructure and beautifying the town's environment. At the same time, we should strengthen the training of local talents, formulate a series of talent training plans, for enterprises and scientific research institutions to send more outstanding talents.

\section{Project source}

The National Natural Science Foundation of China (51978419) ; Natural Science Foundation of Liaoning Province (20180551226)

\section{References}

1. Fan Yang. Analysis on planning strategies of characteristic towns from the perspective of industry and city integration $[\mathrm{J}]$ engineering construction and design,2019(5)

2. Yan Liu. Study on the status quo and countermeasures of characteristic towns in Liaoning province [J] Liaoning economy, 2019 (5)

3. Lijun Li. Policy analysis and development opportunities of characteristic towns -- a case study of characteristic towns in anhui province $[\mathrm{J}]$ modern marketing (business edition), 2019 (7)

4. Zhixiang Chen . Discussion on five key issues in characteristic town $[\mathrm{J}]$ creation, 2018(11)

5. Yang Yang. Problems and countermeasures in the construction of characteristic towns in China [J] beauty and times (urban edition),2018(11)

6. Yi Shen, Lin hao Li, Yuanjia Fu. Study on development path of characteristic town -- a case study of guangxi $[\mathrm{J}]$ commercial economy,2019(04)

7. Yingbo Fang, Wenfang Yi, Mingchun Tang . Development model and policy thinking of characteristic town $[\mathrm{J}]$ commercial economy research 2019(10)

8. Zhengli Hu. Interpretation of the concept of characteristic town and its contemporary significance [J] modern commerce,2019(11)

9. Xiangzhen Tang, Guofang Hang. Problems existing in the construction of characteristic towns and reflections $[\mathrm{J}]$ agricultural development and equipment, 2018(12)

10. Dongning Fan, Jianhui Yao. "three living principles" of characteristic town construction [J] journal of jiamusi vocational college, 2018(11) 